\title{
中国话语原则
}

\section{Principles of Chinese Communication}

The changed and changing China is attracting increasing attention from diverse disciplinary perspectives but a comprehensive, culturally-conscious and so fair understanding has been hard to come by. In this first contribution for the Spanish-speaking community, I outline an account of the general principles underlying contemporary Chinese communication with a view to fostering intercultural dialogue. These take the form of concepts, rules, values, strategies, and historical and cultural relations specific to or characteristic of Chinese discourse. In the process, implications are drawn for correcting universalistic, a-cultural and a-historical conceptions of human communication and for guiding Chinese communication research,

"Shi-xu (PhD, University of Amsterdam) was Research Fellow at the University of Amsterdam, Lecturer at the National University of Singapore and Reader at the University of Ulster, UK. Changjiang Distinguished Professor, he currently directs the Centre for Discourse and Cultural Studies, Hangzhou Normal University as well as the Centre for Contemporary Chinese Discourse Studies (CCCDS), School of Media and International Culture, Zhejiang University. His books in English include Cultural Representations, A Cultural Approach to Discourse, Discourse and Culture, Chinese Discourse Studies, Discourses of the Developing World (with K. Prah \& L. Pardo), Read the Cultural Other (lead-editor) and Discourse as Cultural Struggle (editor). He is founding Editor-in-Chief of Journal of Multicultural Discourses and General Editor of Cultural Discourse Studies Series (both with Routledge) and serves on a dozen of international journal editorial boards. The article is funded by project of the State Social Science Fund, "Constructing a Chinese theory of discourse as masscommunication" (No.12BXW027). 
实践提供了启示与借鉴。

[关键词］文化; 话语；权力；交际；策略； 关系 education and practice.

Key words: Culture; discourse; communication; power; strategies; relation.

In the past three decades or so China has undergone rapid, deep and wide transformations both at home and in relation to the rest of the globe and all signs are that they are accelerating as the old world order is shifting (Jacka, Kipnis \& Sargeson, 2013). In this context China is being watched and viewed from various disciplines, social, economic, political, psychological, legal, historical, etc. (e.g. Barabantseva, 2009; Brown, 2007; Dunford \& Yeung, 2011; Hodge, 1998; Huang, 2003; Shambaugh, 2013; Hua \& Guo, 2007). That does not mean, though, that China is now being understood in new, or fair, ways. More often than not, China continues to be represented as the Other: 'threat' to world security, 'the biggest polluter', 'saboteur' of 'international' law, 'abuser' of human rights, and so on and so forth (Brown, 2007; Chu, 2013; Lee, 2013; Li, 2008).

In this contribution I propose to take a holistic, in particular cultural-communicative, perspective and account for contemporary Chinese society in terms of the ways in which communication or discourse is culturally organized. That is, beyond familiar, often Westcentric, approaches, I shall highlight Chinese cultural characteristics of communication as alternative way of coming to terms with the changed and changing China. This means that contemporary China will be viewed as forms of communication and that I shall draw attention to the Chinese ways of thinking, concepts, norms and values, rules, principles, representations, etc. involved in their communicative interaction. In the process, I shall also discuss their implications for research, education and practice.

At this point there is a stumbling block, however. That is, mainstream theory of discourse and communication, including the conceptions thereof, has largely been blind or at least insensitive to culture (see De Burgh, 2000; Fairclough, 2012; Huang, 2003; Schnell, 1999; Van Dijk, 2012; Williams, 2005; Wodak, 2012; Zhao, 2008). It should be pointed out in particular that while their theory is routinely presented as universal, it is in fact Western in origin and orientation (Shi-xu, 2014: 1-17). Consequently, it could blinker the researcher's view of cultural characteristics of the discourses under study. 
'Culture' is meant here (a) the basic ways of thinking, concepts, categories, values, rules, representations, emotions, strategies, etc. as embodied in the activities as well as artifacts of a community as opposed to those of (a)other communities and (b) the power practices and relations involved in relation to those of the others (Shi-xu, 2014: 26-7). As such, culture is most pervasively and prominently manifested in 'communication' (the former can hardly exist outside of the latter) by which is meant: the social event or activity (an aggregate thereof) in which people use language and other symbolic means through given channels for certain purposes and with certain effects in particular historical and cultural relations. (In parenthesis, although 'communication' and 'discourse' are often used in different ways and carry different emphases, they are understood in this study as overlapping and so used interchangeably.) In this light Chinese communication, for example, is not merely different from that of that of the US-dominated West, but also in a power-differential relation with it. In this sense communication/discourse is by nature and by definition cultural; culture is not external but central to communication/discourse (see also Shi-xu, 2005).

Such a holistic, cultural-communicative, approach can be an effective and productive way of understanding human affairs and societies because discourse, as just alluded to, is the primary site and prevailing mode of socio-cultural life and because, as analytic notion, it brings human agency and subjectivity into sharper relief.

It should be cautioned at the outset that the general propositions to be proffered are not to be taken to be all-encompassing or complete or conclusive. Others regarding different, particular or new aspects and domains of contemporary Chinese discourse should be explored. Besides, these general statements must not be thought to imply that Chinese communication is homogeneous across all sub-groups and situations; it is internally diversified and externally open-ended. These assumptions are formulated largely in response to existing universalistic theory and its intellectual-cultural consequences; in other words they are designed to illuminate qualities and features of contemporary Chinese discourses which would otherwise be smoothed over, obscured or distorted by a-cultural, a-historical theory. It may be added, too, that the present account must not be understood as uniquely Chinese in perspective nor solely about China as object of enquiry. In trying to theorize Chinese forms of discourse, I draw upon culturally diverse perspectives, assimilate different disciplinary concepts and pay attention to globally relevant and related phenomena and 
issues as well. Thus, what I shall do here is to construct a theory of contemporary Chinese discourse that is at once locally grounded and globally minded. In this sense the present endeavour is intended to make possible intercultural dialogue and cross-fertilization on the study of human communication in general and contemporary Chinese communication in particular.

Chinese scholarship has not had a sustained research tradition like the Western discourse analysis which, taken as a whole, can be seen as a discipline that systematically examines levels, segments, processes and social functions of texts and talk, let alone some critical tradition like critical discourse analysis that systematically engages with political issues. But of course that is not to say there have been no similar or parallel works, platforms or relevant intellectuals. Chinese scholarly history possesses most influential treatises or ideas on communication which date back to more than two thousand years ago. One is immediately reminded of such classics as 《易经》 (The Book of Changes), 《论语》 (The Analects), 《道德经》 (The Dao and Its Characteristics), 《文心雕龙》 (Dragon-Carving and the Literary Mind) - below I shall hark back to these when we consider the historical impact of Chinese culture and re-appropriation of classical concepts. Only the concepts, principles and methods contained therein have not led to anything like a modern communication discipline.

In the past few decades, Chinese literary studies and Chinese communication studies, more generally, too, have yielded distinctly Chinese concepts, terms, categories and theories over Chinese forms of communication (Cao, 2008; Chang, 1987; Cheng, 1988; Chen, 2001, 2009; Chu, 1988; Fang \& Faure, 2011; Heisey, 2000a, 2000b; Lee, 2000; Lu, Jia \& Heisey, 2002; 陈先红, 2009; 陈汝东, 1998; 古风, 2010; 胡正荣, 2012; 申小龙, 2001). These have effectively challenge the universality and centrality of Western theory and methodology (Shi-xu, 2009). However, it may be observed that they have usually been restricted to certain aspects of Chinese communication (e.g. rhetoric), domain-specific (e.g. literary) contexts, or particular levels (e.g. moral); like mainstream theory, this Chinese scholarship clearly lacks (inter-)cultural-political consciousness of human/Chinese communication.

In addition, there are now a couple of journals purportedly on Chinese discourse and communication (e.g. Chinese Language and Discourse, Chinese Journal of Communication, Journal of Contemporary Chinese Discourse Studies). They deal with various aspects of the Chinese language, mass communication, journalism, new media, advertising, etc. However, theory 
(as well as methods) used is mostly Western. Indeed, to construct a comprehensive and systematic theory of discourses of contemporary China remains an urgent and challenging task. Earlier I have attempted such a version (Shi-xu, 2014). In the following I shall continue this work and, by continuing to draw upon Chinese classical and contemporary as well as international scholarships, develop a fuller and more precise account.

At the outset of this exposition, let me try to define the theory in terms of its scope, composition, functions and overall objectives. First of all, it is concerned with the discourses (or discourse as a whole) of Mainland China as socialist market-economic society since its reform and opening-up in 1978. Second, it consists in ten general propositions, which variably describe, explain, interpret or evaluate aspects of contemporary Chinese discourse; these aspects may be its properties, norms, habits, rules, strategies, concepts, representations, etc. Third, it is selective and intended specifically to highlight its cultural distinctiveness, regularities, dynamics, complexities, power relations, strengths, weaknesses, especially those features that would be neglected, misrepresented or smoothed over by mainstream a-cultural and a-historical theory and methodology. Ultimately, it is hoped that this theory will contribute to helping the Chinese community and, more generally, the developing, Third World to become critical and productive agents of their own discourse on the one hand and to helping the international community to understand and research more appropriately and adequately the discourses of contemporary China on the other hand.

From a holistic and particularly intercultural point of view, contemporary Chinese discourse (CCD) is a relatively weak, though increasingly influential, 'member' in the current unequal and unfair world order of communication in which the American-West is the dominant power. This 'membership' refers to a variety of the constituent elements of communication, ranging from identity, position, access, control, means, channels, symbols, opportunities, capacity to influence. The Chinese disadvantaged position has obviously to do with the historically evolved and today continued inequitable and hegemonic system and order of world communication. On the other hand, CCD is becoming increasingly powerful with China's political and economic ascendency in the world. On the whole it is part of the marginalized but re-emerging developing, Third World discourse (Nam 2010; 周建华, 2013).

This means that research, practice and pedagogy much first and foremost expose, confront and help transform the culturally unequal and 
unjust human, international communication order whether in society or in scholarship and continues to empower itself as part of the developing-world emancipation.

From a holistic and especially historical and history-conscious vantage point, CCD is a dynamic and creative activity in relation and in response to traditions and other cultures. Chinese communication in the past thirty or so years has undergone tremendous transformation as opposed to what was the case, say, during the Cultural Revolution; many studies have pointed to the new changes and new situations as a challenge to conventional theory (Heisey, 2000a, 2000b; Jia, Lu \& Heisey, 2002; Lee, 2000). Mass participation in public communication, new concepts/values/topics/ language, improved information technology, explosion of social media, increased press freedom, are just some exemplars of the complex and wide-ranging medley of this change. At a deeper, cultural-conscious, level, it may be seen, too, CCD has renounced many older concepts, values and forms and re-appropriated or modernized conventional resources according to new milieu (Shi-xu, 2012).

So for teaching, learning and research and ultimately social practice, this would imply that the agency, creativity and forms of change as well as its evaluation must become the topics of concern or objects of action.

From a rhetorical and especially ethical viewpoint, CCD is guided by the overarching neo-Confucian principle of being and doing: to bring, maintain and enlarge worldly harmony. That is, relational in nature and holistic in worldview, CCD strives to achieve power-balanced harmony, or equilibrium, in society (平天下, peace of humanity under the heaven) as the ultimate moral principle and it does so by conflict-avoidance, empathy with others, self-sacrifice, conviviality, etc. in speaking and understanding. As global moral principle, equilibrium applies to all settings and domains of discourse, ranging from the public to private, from the domestic to international, from the political, economic, social, ethnic, environmental, to military. China has vociferously spoken for example for 'harmonious-Chinese-society' and 'harmonious world' over the past few years both at home and abroad. Chinese people would rarely criticize someone without an appreciative preface; faced with animosity they would seldom put up opposition before showing propriety. In mass media, the press tends to refrain from giving news that would destabilize or disrupt society.

Under the general principle of equilibrium, there are three subordinate rules that are worthy of special note here. First, in the Chinese discourse 
context, the hearer/reader and so interpretation and response play a central and sometimes dominant role in the communicative event. That is, the producer, instead of being self-goal oriented, may more often than not attempt to establish or maintain or enhance a harmonious relationship by self-sacrifice and attending to the interest of the interlocutor. Moreover, it is commonly understood that the meaning of discourse lies with the latter. Second, CCD is guided by the subordinate rule of inclusiveness and diversity (e.g. 和而不同, being harmonious but different). This applies to such topics as opinions, political-economic systems, ethnicities, cultures and so on and so also means respect for them. The Chinese open-door policy and its practice in the past three or more decades are perhaps the most conspicuous manifestation of its cultural inclusiveness and diversity. In recent years, China has systematically advocated multilateral and multicultural geopolitics and diplomacy. Thirdly, CCD is undergirded by the rule of social rite (礼), as embodied in such Confucian teachings as 非礼勿 言, 非礼勿视, 非礼勿听 (speak no evil, look at no evil, listen to no evil); 礼 尚往来 ('One good turn deserves another'); 已所不欲, 勿施于人 (Do not do unto others what you would not want others to do unto you). That is, people are supposed to observe the rule of humane, polite and amicable manner in interpersonal or intergroup activity.

The Chinese communicative ethics can be used as not only a norm to guide social practice, but also a yardstick to evaluate it. This implies that it will be necessary and useful to pay attention to the discursive strategies, tools and processes that realize or maintain the general moral guideline as well as the particular rules of Chinese discourse.

Still another macro, ubiquitous, global characteristic of CCD, from the perspective of the philosophy of the meaning of human communication, is its concept of meaning with respect to discursive production and comprehension. Historically speaking, Chinese Daoism and Buddhism have deep mistrust of language in relation to meaning and this tradition has penetrating influence in Chinese experience. Rhetorically speaking, disconnection or discrepancy or distance between discourse and meaning is regarded as rule, fact, challenge, aesthetic goal of meaning production and meaning comprehension. From a humanistic point of view, listeners and readers are understood to be imaginative, emotional and poetic. From a holistic point of view, finally, meaning, like the universe, never stays still but will change with times. Thus, metaphors (especially 成语, four-character proverbs), poetic lines, generalizations, brevity, quiescence, or even silences, are of common occurrence in CCD. 
So in research, education and practice, questions of meaning should be continuous, answers to them open-ended, speakers/writers on the one side and listeners/readers on the other modest. It will also be interesting and useful to attend to issues of the degree of 'distance/disconnection/ discrepancy' of meaning with regard to specific contexts: e.g. how much is enough and appropriate? In addition, forms, techniques and tools of meaning management should become focal points of attention.

From a geo-political-economic perspective, CCD is both conditioned by socio-economic development situations and guided by the short-term and long-term socio-economic development goals. ('Development' is used in the special sense of the social economic conditions and goals of the Third World/developing countries, see Shi-xu, Prah \& Pardo, 2015). That is to say, on the one hand, CCD is characterized by various features to do with history of imperialist aggression, domination and exploitation, low levels of industrialization, poverty, social and regional inequality, lack of educational and health resources, inefficiency, dependency, corruption, environmental pressure, but at the same time ascendancy in political and economic power as part of the Third World's global re-emergence. On the other hand, CCD is guided by the Chinese social economic policy and goals of development (including e.g. those of a moderately well-off society by 2020 and of a moderately developed society by 2050) and so the relevant values and principles. Thus, CCD may be seen as at once constrained by conditions of (under-) development and empowered by new achievements of development. The difficulties and advances of the Chinese media discourse are a case in point. At the same time, CCD is clearly geared to the concerns, values and objectives of China's development. Development of and in agriculture, industry, science and technology, national defense and governance is not only a common theme but also an overarching value in everyday Chinese discourse. Further, it is regarded as the basic method and means to solving China's problems and reaching its goals. It should be pointed out here that development is not simply a national characteristic but more of a culture one in that it is shared by the rest of the developing world.

Discourse research should then take development as a central topic because it is one of the best vantage point from which to understand China; moreover, studying development from a discourse perspective can also help China with its development missions by e.g. identifying discursive strengths and weaknesses as well as devising new forms of development 
discourse. Education then ought to focus on discourses of development as an effective way of training.

CCD is dialectic in thinking in that Chinese may see totalities of things and so connections, of myriad sorts, between things and that this is typically the case when there is trouble, adversity, contradiction, or opposition. Because of its function of rhetorically neutralizing the unfavourable situation, this way of communication is regarded as wise and preferred. The dialectic feature is however context-bound and so local. But in comparison with Western forms of communication, the dialectic thinking may be said to be more frequent and more wide-ranging in discursive settings. The Chinese propensity is reflected in ordinary life as well as in scholarly approaches. Thus, in times of diplomatic, international disputes, for example, Chinese would stress, mutual benefit, long-term interest, over-all planning, etc. When there is a disaster, they would be encouraged to see the fortunate side. When there is a crisis, they would incline to look for opportunities. By the same token, in academic research as well as in everyday affairs, they would not submit to the idea that something can be absolutely bad, wrong or false; to them such things also have the good, correct and true side. Consequently their visions and versions are characteristically complex and sophisticated.

To study contemporary Chinese discourse then one should try to identify what kind of situations obtains when a dialectic discourse occurs and examine how the dialectic is composed of, if this is precisely or fully applied and to what use it is put. Educators should highlight the wisdom of this form of thought and talk and advocate its use in specific types of circumstance. In social practice, people might as well try to make use of it as far and as appropriately as possible.

Within CCD, there is (still) an important social value of authority which comes from the two-thousand Confucian, hierarchical tradition and it operates particularly when knowledge or morality is at stake. That is, authority is often to be the condition of the arbiter of knowledge or morality. The contemporary Chinese notion of authority may pertain to power, social position, expertise, seniority, moral deeds, masculinity and even geopolitical regions (e.g. the capital city of Beijing and the metropolis of Shanghai) as such authority can function as the norm, standard, or point of reference when adjudication of truths or judgement of morality is to be made. It may be added, too, that in modern and contemporary China, natural science has been held as truer and so more respectable form of knowledge than social science and common sense and therefore commands 
more authority. Thus, when, for example, a social issue of frugality and economizing is discussed, natural scientists would be called upon as the authority and so become the main speakers. When an endemic N7H9, an entirely new form of virus, breaks out, an expert of any other health subject may be enlisted to speak. When a school building in an underdeveloped, poor area collapses during an earthquake, an academician could be asked to explain. That said, it should be noted that, especially as a result of China's opening-up, globalization and spread of information technology, this remnant Chinese value is losing grip especially with the younger Chinese generation.

Researchers of CCD should pay acute attention to the identity of the people taken as authority, the specific nature and function of the authority, the consequences, real or potential, of such use of authority. But above all, they should critically examine the suitability of the authority to phenomena in question. In education, the urgent task ought to enhance critical awareness of use of communicative authority, to encourage discussion of new conditions and boundaries of authority for communication.

Like authority, face is also an important value in CCD; like authority, too, it is salient only in certain contexts. The Chinese notion of face is a valued self-image of being morally upright, socially amicable and generous, financially affluent or intellectually bright or a combination of these. The Chinese face can be that of an individual, family, group, tribe, organisation or nation. In this sense, it is an important part of Chinese cultural consciousness. This face, by the way, has the dramatic quality of being something of the front-stage as opposed to the back-stage. Such face has various expressions in Chinese: 脸, 面子, 脸面, 表面, 情面, 形象, 印象, 外表 - they carry different shades of meaning with respect to that general notion; people can do various kinds of things to the Chinese face: 爱面子 (take face seriously), 有面子 (have face), 给面子 (give face), 面子工程 (face project), 不留情面 (not to save face). This Chinese face is a distinct cultural trait because in CCD it has bigger role and people do more face work than in say Western forms of communication. Often, to keep face, Chinese may go extra lengths and sacrifice their self-interest. In international business, for instance, they may give in to demands or give up economic profits for the sake of the face of their company or their country.

For empirical research, scholars and students of contemporary Chinese discourse should pay special attention to the specific nature of the face in question, whose face is being constructed, how this is done and for what purposes. Crucially important, too, is the question of what kind of 
consequences a particular piece of face work produces. Educators should then promote debates over the nature, ethics and use of face in different contexts, private and public, corporate and institutional, of cities and the state, etc. In practice, for instance in managing a company, city or nation, one should develop a clear and critical vision of what constitutes the relevant face, take strategic measures to safeguard or enhance it, and make reserved plans to mend it when crisis occurs.

Again from a moral point of view, CCD has a strong cultural, emotional value of patriotism though it is clearly restricted to public settings of national politics or otherwise where the topic is broached. It should be understood that this is closely connected with the memory of the modern history in which the Chinese suffered for more than one and half centuries of foreign aggression, exploitation and humiliation, and further, the entire Chinese history of patriotism (费孝通, 1999). Also, it should be realized that this particular 'national-emotional' value of patriotism is basically transnational and more specifically cultural because it is shared by the Third World, developing nations. Chinese patriotism has functioned to mobilize the nation, lift up the people's spirit and encourage them to make greater contributions to the Chinese nation. The buzz phrase in current China, the Chinese Dream, is filled with this emotion. In Chinese education, patriotism is one of the most important elements. When sovereignty, national security, national unity, territorial integrity and the like are at stake, when the modern history of colonialist and imperialist aggression is discussed, when an important scientific discovery is made, or on the National Day or other national commemoration occasions, the emotion of patriotism would feature prominently.

Communication research may be conducted into the historical process and international and intercultural relations of the Chinese patriotic discourse. Investigations should also be made into the reception and broader effects of such discourse. Close examination is also needed on how Chinese patriotic discourse is received and responded by different international communities. Especially international education must take a world-historical perspective in the discussion on the phenomenon.

Finally, from a communication-aesthetic viewpoint, CCD has the particular quality and norm of being 'beautiful' to the Chinese community ( 黄力之, 2001; 罗迪江, 2006; 徐思益, 1986). The Chinese literary tradition has it, 言之无文, 行而不远 (inelegant speech will not carry far). The Chinese linguistic structure and system also supply the bases and parameters whereby a specific form of 'beauty' of discourse is rendered possible: the 
Chinese ideograms, characters, tones. In addition, Chinese culture in general and literary cannons in particular set standards and categories of expression: 意境，神韵，风骨，风格，言不尽意，etc. Consequently，it is common to observe parallel structures, rhythmic speech, melodious sounds, rich imagery in CCD. Whilst such aesthetic qualities and expectations are variable in degree with respect to persons, situations, genres, etc., it is striking that they are manifested widely in everyday as well as academic settings of CCD.

Researchers of CCD should look at the aesthetic forms and qualities from both productive and receptive perspectives. They should develop clear criteria of discourse aesthetics for both critique and practical instruction. Training and practice should of course concentrate on the mastery of the aesthetic tools and strategies of CCD so that members can render their discourse more beautiful and effective.

In this contribution I have formulated a cultural understanding of contemporary Chinese communication in the form of ten general propositions. Specifically, it is a Chinese one in the sense that it proceeds from a Chinese intellectual and cultural-political perspective, reflects uniquely Chinese discursive characteristics as a whole, and, further, is oriented to answering to practical needs and concerns of contemporary Chinese society on the one hand and to correcting conventional, universalistic and hegemonic views of Chinese communication on the other.

Obviously, the portrait of contemporary Chinese discourse canvassed here is necessarily incomplete and inclusive. Other aspects, levels and dimensions of Chinese discourse are still to be filled in. In particular, a number of urgent tasks are to be engaged in. To begin with, scholars and students of Chinese discourse and communication need to reflect from an intercultural and especially Eastern perspective on mainstream theory in terms of its cultural-intellectual bias and human consequences. Next, they must look back at Eastern, Asian, Chinese cultural and scholarly legacies in order to tap into their rich resources. Most centrally, they should collaborate from different disciplinary angles and intra/intercultural perspectives to contribute to the theoretical development on contemporary Chinese communication. In the process and in particular, they should try to specify the commonality of Chinese discourse with those of the developing, Third World on the side and its relations with the Western discourses on the other hand.

After all, the present attempt is not just meant for Chinese discourse scholarship. As alluded to above, the present work is intended as an 
endeavor in Cultural Discourse Studies (Shi-xu, 2015) in the hope that scholars and students from other cultural communities will also start thinking and working on a similar line to create locally grounded and globally minded theory that is appropriate and productive for their local societies.

\section{REFERENCES}

Barabantseva, E., 2009. Change vs. order: Shijie meets Tianxia in China's interactions with the world. Alternatives: Global, Local, Political 34: 129-155.

Brown, K., 2007. Struggling Giant: China in the 21st Century. London: Anthem Press.

Cao, S. Q., 2008. The discourse of Chinese literary theory and the dialogue between Western and Chinese literary theories. Journal of Multicultural Discourses 3, 1: 1-15.

Chang, C. Y., 1987. Chinese philosophy and contemporary human communication theory. In D. L. Kincaid (ed.), Communication Theory: Eastern and Western perspectives. San Diego, CA: Academic Press: 23-43.

Chen, G. M., 2001. Towards transcultural understanding: A harmony theory of Chinese communication. In V. H. Milhouse, M. K. Asante \& P. O. Nwosu (eds.), Transculture: Interdisciplinary perspectives on cross-cultural relations. Thousand Oaks, CA: Sage: 55-70.

,-- 2009 . Beyond the dichotomy of communication studies. Asian Journal of Communication 19, 4: 398-411.

Cheng, C. Y., 1988. The I Ching as a symbolic system of integrated communication. In W. Dissanayake (ed.), Communication theory: The Asian perspective. Singapore: Asian Mass Communication Research and Information Centre: 79-104.

Chu, B., 2013. Chinese Whispers: Why Everything You've Heard About China is Wrong. London: Weidenfeld \& Nicolson.

Chu, L. L., 1988. Mass communication theory: A Chinese perspective. In W. Dissanayake (ed.), Communication theory: The Asian perspective. Singapore: Asian Mass Communication Research and Information Centre: 126-138.

Curran, J. \& M. J. Park (eds.), 2000. De-Westernizing Media Studies. London: Routledge.

De Burgh, H., 2000. Chinese journalism and the academy: The politics and pedagogy of the media. Journalism Studies 1: 549-558. 
Dunford, M. and G. Yeung, 2011. Towards global convergence: Emerging economies, the rise of China and western sunset? European Urban and Regional Studies 18, 1: 22-46.

Fairclough, N., 2012. Critical discourse analysis. In J. P. Gee \& M. Handford (eds.), The Routledge Handbook of Discourse Analysis. London and New York: Routledge: 9-20.

Fang, T. and G. O. Faure, 2011. Chinese communication characteristics: A Yin Yang perspective. International Journal of Intercultural Relations 35, 3: 320-333.

Heisey, D. R., 2000a. Introduction: Chinese perspectives coming of age in the West and serving as a balance in theory and practice. In D. R. Heisey (ed.), Chinese Perspectives in Rhetoric and Communication. Stamford, $\mathrm{CN}$ : Ablex: xi-xx.

-- (ed.), 2000b. Chinese perspectives in rhetoric and communication. Stamford, CT: Ablex.

Hodge, B., 1998. The politics of Chinese language and culture: The art of reading dragons. New York: Routledge.

Hua, S. P. \& S. J. Guo (eds.), 2007. China in the Twenty-first Century: challenges and opportunities. New York, NY: Palgrave Macmillan.

Huang, C., 2003. Transitional media vs. normative theories: Schramm, Altschull, and China. Journal of Communication 53: 444-459.

Jacka, T., A. B. Kipnis \& S. Sargeson, 2013. Contemporary China: Society and Social Change. Cambridge: Cambridge University Press.

Jia, W., X. Lu \& D. R. Heisey (eds.), 2002. Chinese communication theory and research: Reflections, new frontiers and new directions. Westport, Conn.: Praeger.

Lee, C. C., 2000. Chinese communication: Prisms, trajectories, and modes of understanding. In C. C. Lee (ed.), Power, money, and media: Communication patterns and bureaucratic control in cultural China. Evanston, IL: Northwestern University Press: 1-44.

Lee, J., 2013. Australia's 2015 Defence White Paper: seeking strategic opportunities in Southeast Asia to help manage China's peaceful rise. Contemporary Southeast Asia: a journal of international \& strategic affairs 35, 3: 395-422.

Li, R., 2008. A Rising China and Security in East Asia: Identity Construction and Security Discourse. London: Routledge.

Lu, X., W. Jia \& D. R. Heisey (eds.), 2002. Chinese communication studies: Contexts and comparisons. Westport, Conn: Praeger. 
Nam, P. S., 2010. China's emergence as a key player in the global order and its impacts on geopolitics in central Asia. International Area Review 13, 1: $155-165$.

Schnell, J. A., 1999. Perspectives on communication in the People's Republic of China. Lanham, MD: Lexington Books.

Shambaugh, D., 2013. China Goes Global: The Partial Power. Oxford: Oxford University Press.

Shi-xu, 2005. A Cultural Approach to Discourse. Basingstoke, England: Palgrave Macmillan.

--, 2009. Reconstructing eastern paradigms of discourse studies. Journal of Multicultural Discourses 4, 1: 29-48.

--, 2012. Understanding contemporary Chinese political communication: A historico-intercultural analysis and assessment of its discourse of human rights. Journal of Language and Politics 11, 1: 93-114.

--, 2014. Chinese Discourse Studies. Basingstoke, England: Palgrave Macmillan.

--, 2015. Cultural Discourse Studies. In K. Tracy, C. Ilie \& T. Sandel (eds.), International Encyclopedia of Language and Social Interaction. Malden, MA: Wiley-Blackwell.

--, K.K. Prah \& L. Parodo, 2015. Discourses of the Developing World: Researching properties, problems and potentials. London: Routledge.

Van Dijk, T. A., 2012. Discourse and knowledge. In J. P. Gee \& M. Handford (eds.), The Routledge Handbook of Discourse Analysis. London and New York: Routledge: 587-603.

Williams, J. W., 2005. American scholarship on Chinese media and mass communication: Critiquing the lens. Joint Conference on Chinese Communication Studies, Xiamen University, Xiamen, People's Republic of China, December.

Wodak, R., 2012. Politics as usual: Investigating political discourse in action. In J. P. Gee \& M. Handford (eds), The Routledge Handbook of Discourse Analysis. London and New York: Routledge: 525-540.

Zhao, Y. Z., 2008. Communication in China: Political economy, power, and conflict. Lanham, MD: Rowman \& Littlefield Publishers.

陈汝东, 1998, 语言伦理理论 $[J]$ 。语文建设, 12：25-8。

陈先红, 2009, 新媒体与公共关系研究 [M]。武汉: 武汉大学出版社。

费孝通（编），1999，中华民族多元一体格局（修订本） [M]。北京：中央民 族大学出版社。

胡正荣, 2012 , 新媒体与当代中国社会 $[\mathrm{M}]$ 。上海：上海交通大学出版社。

黄力之, 2001, 全球化背景下的中国问题与中国话语一一中国审美文化走向的 
一个观察视角 $[J]$ 。文艺理论与批评，(3)：4-14。

古风, 2010, 话语、中国话语与文学理论的创新 $[J]$ 。贵州社会科学, (2) : $46-53$ 。

罗迪江, 2006, 美学语言学视域中的言语交际求美倾向 $[\mathrm{J}]$ 。广东外语外贸大 学学报, (3) : 36-39。

申小龙, 2001 , 汉语语法学 [M]。南京: 江苏教育出版社。

施旭, 2010, 文化话语研究: 探索中国的理论、方法与问题 [M]。北京：北京 大学出版社。

徐思益, 1986，说话的艺术 $[\mathrm{J}]$ 。语文建设，6。

周建华、程健康、王国成，2013，全球化背景下我国文化安全面临的挑战与对 策 $[\mathrm{J}]$ 。陕西行政学院学报, $27(1)$ : 72-5。 